УДК $821.112 .2-2: 792.03$

DOI: https://doi.org/10.31499/2415-8828.2.2021.246096

\title{
Лариса Федоренко*
}

\section{АЛЬФРЕД ДЬОБЛІН VS. БЕРТОЛЬТ БРЕХТ: РЕЦЕПЦІЯ ЖАНРУ LEHRSTÜCК У ДРАМАТУРГІї А. ДЬОБЛІНА}

Стаття присвячена рецепції брехтівського жанру Lehrstück («навчальної» або «повчальної» п’єси) в драматургії Альфреда Дьобліна. На основі порівняльно-зіставного аналізу п’єси «Шлюб» у дослідженні представлені естетико-типологічні ознаки, які споріднюють «навчальні» п'єси Б. Брехта та А. Дьобліна (відмова від театральної ілюзії, наявність епічних елементів та музики як складових елементів драми, використання текстових та ілюстративних проєкцій, зонгів, речитативів 3 музичним супроводом, наявність промовця (коментатора) і хору, можливість імпровізації та модифікації текстового матеріалу п’єси), що дає підстави розглядати п’єсу А. Дьобліна як концептуальне наслідування та/або продовження теорії та практики авторського жанру Lehrstück Б. Брехта.

Ключові слова: Lehrstück, навчальна п’єса, повчальна п’єса, Альфред Дьоблін, брехтівський театр, діалектичний театр, експериментальний театр.

Fedorenko Larysa. Alfred Döblin vs. Bertolt Brecht: Reception of the Genre Lehrstück in A. Döblin's drama.

The article is devoted to the drama of Bertolt Brecht and Alfred Döblin. On the material of A. Döblin's play «The Marriage» analyzes the typological factors of the genre Lehrstück («learning» or «didactic» play), which became widespread as Brecht's authorial innovation. The purpose of the article: on the basis of comparative analysis of Lehrstück by B. Brecht and the play «The Marriage» by A. Döblin to explore their formal and poetic factors and to conclude about the common and distinctive features of artistic and aesthetic intention of the genre Lehrstück in the works of both playwrights.

The source base of the research is represented by literary studies of Günter Hartung, Jan Knopf, Klaus-Dieter Krabiel, Heiner Müller, Rainer Steinweg, Bernhard Klaus Tragelehn, Florian Vaßen, Oleksandr Chirkov. To achieve this goal, the following research methods were used: cultural-historical, comparative-historical, structuralsemantic, descriptive, literary analysis and synthesis. The study presents the main stages of the genre in the work of Brecht and focuses on the initial period of origin of the «learning» or «didactic» play, which is also relevant to the drama of A. Döblin. The play «The Marriage» contains three scenes, a prologue and an interlude. Thematically, all the scenes are united by a common plot core - showing the breakup of marriage and family due to external circumstances. Family and marital relationships fail regardless of social status or financial status. Results and conclusions: The article proves that A. Döblin's play «The Marriage» has a number of aesthetic and typological features that make it related to Brecht's «didactic» plays: rejection of theatrical scenery, props, that is, everything that creates a theatrical illusion; the presence of epic elements and music as components of drama; use of text and illustrative projections, songs, recitatives with musical accompaniment; presence of a speaker (commentator) and a choir; the inclusion of the author's commentary, which states the theme and issues of the drama, as well as explains how the play is constructed, emphasizes the probable educational, educational, instructive influence; the presence of director's remarks that explain the options for the stage embodiment of the play; the ability to improvise, modify the text of the play and release individual scenes according to the purpose and type of production. A generalized analysis of the existing typological characteristics gives grounds to consider the play «The Marriage» by A. Döblin as a conceptual imitation and / or continuation of the theory and practice of the author's genre Lehrstück B. Brecht.

Keywords: Lehrstück, learning play, didactic play, Alfred Döblin, Brecht Theater, dialectical theater, experimental theater.

Метою статті є теоретико-літературний аналіз п’єси «Шлюб» (Die Ehe, 1930) німецького письменника та драматурга доби Ваймарської Республіки

\footnotetext{
* Лариса Федоренко, кандидатка філологічних наук, доцентка кафедри германської філології та зарубіжної літератури Житомирського державного університету імені Івана Франка (Житомир, Україна); e-mail: fvm34@ukr.net.
} 
Альфреда Дьобліна (1878-1957) в контексті концепції жанру Lehrstück Бертольта Брехта (1898-1956).

Жанр Lehrstück виник у Німеччині у 1930-ті роки як спільна авторська новація драматурга Б. Брехта, композиторів Курта Вайля (1900-1950), Пауля Гіндеміта (1895-1963) та Ганса Айслера (1898-1962).

Назва жанру Lehrstück у буквальному перекладі з німецької мови означає «повчальна п’єса», але відповідно до авторської інтенції Б. Брехта Lehrstück є «навчальною вправою» (learning-play, Lern-Spiel) для теоретико-практичної підготовки гравців-аматорів до діяльності в суспільно-політичному житті [Брехт 2009, с. 6].

Lehrstück як авторський жанр Б. Брехта є до сьогодні актуальним об'єктом дослідження зарубіжних і вітчизняних науковців, серед яких передусім назвемо Гюнтера Гартунга (дослідження генези та інтертекстуальних зв'язків драматургії Брехта) [Hartung 2004], Яна Кнопфа (дослідження джерел, еволюції, поетики, структуралістський аналіз драматургії Брехта) [Knopf 2002], Клауса-Дітера Крабіля (дослідження витоків Lehrstück як вокально-музичного жанру в контексті музичної культури Німеччини другої половини 1920-х років) [Krabiel 1993], Гайнера Мюллера (теоретико-практичне переосмислення драматургії Брехта) [Müller 1986], Райнера Штайнвега (дослідження генези та поетики жанру Lehrstück у річищі театральної педагогіки) [Steinweg 1976; 2005], Бернгарда Клауса Трагелена (літературознавчий аналіз жанру Lehrstück) [Tragelehn 1978], Флоріана Фассена (дослідження становлення жанру як LernSpiel (навчальної гри)) [Vaßen 1995], Олександра Чиркова (дослідження жанру в контексті теорії та поетики епічної драми, а також діалектичного театру) [Чирков 1981; Чирков 2006; Чирков 2009].

До 1960-х років брехтівський жанр Lehrstück перебував на периферії літературознавчих та мистецьких досліджень у Німеччині та в Україні. Lehrstück розглядався як політична тезисна п’єса, яка, на думку науковців, не мала естетичної вартості і була перехідним етапом у творчості Б. Брехта.

Інтерес до жанру відновився в Німеччині на початку 1970-х років завдяки театрально-педагогічному дослідженню Райнера Штайнвега [Steinweg 2005], який реконструював теорію брехтівської театральної новації за коментарями, ремарками та короткими примітками драматурга періоду 1929-1956 років та провів низку практичних експериментів у річищі театральної педагогіки. Відтак P. Штайнвег визначає жанр Lehrstück як «теорію політично-естетичного виховання», модель якої він називає «театром майбутнього» [Steinweg 1976; 2005].

У 1981 році в Україні виходить друком книга Олександра Чиркова «Бертольт Брехт. Життя і творчість», у якій окремий розділ присвячено Lehrstück [Чирков 1981]. Ламаючи усталену на той час у вітчизняному літературознавстві традицію скептичного ставлення до жанру, науковець розглядає Lehrstück як «лабораторію епічної драми» [Чирков 1981, с. 54]. Проте концепція українського дослідника в тодішньому літературознавстві пройшла майже непоміченою.

На початку 1990-х років дослідження Lehrstück обмежувалися театральнопедагогічними експериментами, літературознавчі ж дискусії про жанр за браком фактичного матеріалу, здавалося б, були вичерпані. Розпад НДР та СРСР зумовив цілковиту втрату інтересу західної та вітчизняної інтелігенції до будьякої соціалістичної та комуністичної літератури. Оскільки театральні діячі й естети відчували відразу до всього повчального, дидактичного на сцені, п'єси в жанрі Lehrstück швидко набули негативних характеристик, бо мали на меті, як 
убачала критика, нівелювати особистість в їі унікальності і «навчати» глядачів та акторів підкорюватися «безликому» колективу, іншими словами, диктатурі комуністичної партії. Про Lehrstück знову забули.

За цих умов у 1993 році в Німеччині з'являється фундаментальне дослідження Клауса-Дітера Крабіля «Брехтівські Lehrstücke. Виникнення i розвиток драматичного жанру», що $€$ певною мірою антиштайнвезькою концепцією Lehrstück [Krabiel 1993]. 3 огляду на те, що п’єси в жанрі Lehrstück є творами, покладеними на музику, дослідник доходить висновку, що Lehrstück не $\epsilon$ набутком драматургіï, а за своїми витоками, формою й призначенням належить до вокально-музичного жанру. Революційне на той час твердження К.-Д. Крабіля не знайшло підтримки ні в літературно-критичних, ані музикознавчих колах, проте відродило інтерес до жанру. Літературна суперечка про жанр між Райнером Штайнвегом та Клаусом-Дітером Крабілем триває й досі, залучаючи в дебати все ширше коло літературознавців.

Український літературознавець Олександр Чирков у подальших наукових студіях визначає жанр як авторську модель політичного театру та як важливий щабель драматургічних пошуках Брехта на шляху до діалектичного театру [Чирков 2009].

Новизною дослідження, викладеної у статті, $\epsilon$ аналіз естетикопоетилогічних характеристик драматургії А. Дьобліна в контексті жанру Lehrstück Б. Брехта.

Для досягнення поставленої мети були використані такі методи дослідження: культурно-історичний, порівняльно-історичний, структурносемантичний, описовий, метод зіставлення, літературознавчий аналіз та синтез.

Наявні літературознавчі дослідження жанру на матеріалі драматургії Б. Брехта [Брехт 2009; Федоренко 2020] дають підстави виокремити чотири етапи становлення Lehrstück.

\section{Етапи становлення жанру Lehrstück у творчості Б. Брехта} (1929-1930)

I. Період «навчальної» або «повчальної» п’сси (умовні Lehrstück)

(«Переліт через океан», «Баденська навчальна драма про згоду», «Свята Іоанна скотобоєнь», «Хлібна лавка» (фрагмент), «Асоиіальний мерзотник Ваал» (фрагмент), «Той, щзо каже так/Той, щзо каже ні»).

II. Оформлення жанру Lehrstück («навчальна гра» без глядача) (лютий 1930)

(«3 нічого не буде нічого» (фрагмент), «Загибель егоїста Йоганна Фатиера» (фрагмент), «Той, щзо каже так (Конкретизація)» (початкова редакиія «Заходу»), «Захід»).

III. Подальша теоретико-практична розробка жанру (власне Lehrstück) (1931-1956)

(«Виняток $i$ правило», «Горації $і$ Куріаціï», «Бюшінা» (фрагмент), «Життя Галілея» (план Lehrstück).

\section{IV. Від Lehrstück до епічного театру.}

(«Maтu»).

На кожному окремому етапі становлення Lehrstück набували якісно нових характеристик. Загалом можна накреслити таку тенденцію розвитку жанру: повчальна п'єса експериментального характеру $\rightarrow$ повчальна п'єса з елементами притчовості $\rightarrow$ повчальна п'єса з акцентом на аналітичну позицію реципієнта $\rightarrow$ Lern-Spiel (навчальна гра) $\rightarrow$ навчальна п’єса з елементами епічної і діалектичної драматургії [Федоренко 2020]. 
Для нашого дослідження є релевантним перший етап, а саме період «навчальної», або «повчальної», п’єси (1929-1930), адже саме тоді виникають перші експерименти в жанрі Lehrstück у творчості Б. Брехта.

Звернімося до докладного аналізу поетико-драматургічних характеристик першого етапу становлення Lehrstück.

Зародження жанру ознаменувало собою появу його перших характерних особливостей у драматургії Б. Брехта, серед яких передовсім назвемо:

-експериментально-дослідницький характер театрального дійства, у якому драматичний текст постає насамперед як експериментально-дослідницька вправа, як процес-гра, засобом якої є мистецтво;

-демократизація мистецтва, унаслідок якої сценічний твір еволюціонує до педагогічно вмотивованого, а також прикладного мистецтва для аматорів, а не професійних акторів;

-Lehrstück пропонує нову модель театру, що ліквідує роз'єднання глядацької зали і сцени (за брехтівським принципом: «Краще діяти, аніж співчувати»). Глядач такого театру стає водночас учасником дійства, який може впливати на розвиток подій у п’єсі;

- посилення «повчального» компонента в драматургії. Театральні тексти Б. Брехта починають акцентувати певне «повчання», спонукають до аналізу і доповнення, відтак театр крізь призму Lehrstück постає як «навчально-виховна установа»;

-застосування проєкцій основних ідей як наочний допоміжний засіб «навчання»;

- умовність, алегоричність, високий ступінь абстрактності зображеного;

-притчовий характер драматургії, що виявляється в концентрованому показі міжлюдських стосунків у порівняльно-показовій формі;

-наявність хорів, які коментують дію, заохочують акторів («гравців»), апелюють до глядачів;

- введення «коментарів» - аналітико-повчальних частин, які промовляють самі виконавці;

- навчання діалектики як аналітичного способу мислення. Діалектика стає концептуальним ядром жанру. За авторською інтенцією Брехта, жанр Lehrstück - це театр діалектичний, у якому п'єси є не театральним видовищем для естетичної насолоди публіки, а вправою (Lern-Spiel) для тренування діалектичного мислення учасників процесу-гри;

-персонажі Lehrstück - суто умовні фігури, позбавлені будь-яких індивідуальних характеристик;

-п’єса може містити «асоціальний» зразок, що потребує корекції;

- учасник приміряє на себе різноманітні соціальні «маски», демонструючи сучасні міжлюдські стосунки («панорамність» зображення);

- стислий, тезисний виклад сцен;

- сценічна дія, що включає процес зміни «вихідного» тексту;

- навчальний «матеріал» із високим ступенем абстрагованості (герой Lehrstück - певний соціальний комплекс, згусток соціально-економікополітичних характеристик. Протагоністи драми є «порожніми рамками», які учасники мають заповнити своїм життям);

- мова Lehrstück - чітка і сувора, майже біблійно-патетична [Брехт 2009; Федоренко 2021].

Прикметно, що дьоблінівська п’єса побачила світ у 1930 році, тобто майже одночасно з виникненням перших п’єс Брехта у жанрі Lehrstück. Не менш 
цікавим видається також те, що жанрове позначення для своєї п'єси А. Дьоблін обирає саме Lehrstück, через що автори - з одного боку - Б. Брехт та К. Вайль, 3 іншого - А. Дьоблін - мали один до одного претензії щодо авторського права. Проте, виходячи навіть із суто хронологічних міркувань, першість, мабуть, усе ж на боці Б. Брехта. Адже вперше поняття Lehrstück пролунало з вуст Б. Брехта та його співавторів 28 липня 1929 року на музичному фестивалі «Нова музика» в німецькому курортному містечку Баден-Бадені, де були представлені перші п’єси Б. Брехта в жанрі Lehrstück - «Переліт Ліндбергів» та «Баденська начальна драма про згоду». Прозвучавши вперше як назва твору, а не жанру («Das Lehrstück» («Навчальна драма») була початковою назвою «Баденської навчальної драми про згоду»), це поняття швидко вкоренилося як модне слово в театрально-музичній практиці.

Прем’єра постановки п’єси «Шлюб» А. Дьобліна, яка мала на меті показати «руйнівний вплив економічної системи капіталізму на людські взаємовідносини у шлюбі та сім’і» [Prangel 1987], відбулася у 1930 році в німецькому місті Мюнхені.

П’єса містить три сцени, пролог та інтермедію. Тематично всі сцени об'єднані спільним сюжетним ядром - показ розпаду шлюбу та сім'ї з вини зовнішніх обставин. Сімейні та подружні зв'язки зазнають краху незалежно від соціального статусу та фінансового становища.

Сцена 1 зображує молоде подружжя, яке мешкає в батьків жінки. Молодий чоловік приходить додому й повідомляє, що втратив роботу. Саме в цей день його дружина дізнається, що вагітна. У відчаї через скрутне становище сім’ї молода жінка звертається до лікаря 3 проханням зробити ій аборт. Лікар відмовляється, бо це заборонено законом. У соціальній службі, у фармацевта молода жінка також стикається з холодним презирством та байдужістю. Урештірешт, вона потрапляє до рук підпільної акушерки і позбувається життя через невдалу операцію.

Хор жінок коментує дійство під музичний супровід: «Ми маємо народжувати дітей - так сказала держава. Чим годувати дітей - держава не сказала. Таке наше життя, яке котиться шкереберть. Ми просто мурашня, яка бореться й терпить. Кому яке діло до непотрібу?» [Döblin 1931, c. 185] ․ $^{1}$

У сцені 2 ідеться про багатодітну родину садівника Г., яка тісниться в крихітній кімнатці і марно шукає нове помешкання. Коли в нестерпних житлових умовах найменша 3 восьми дітей, а згодом i батько сімейства помирають, велика родина цілковито розпадається: діти опиняються в різних притулках, а їхня мати потрапляє в богадільню.

Наприкінці сцени персонаж у ролі промовця виголошує:

ПРОМОВЕЦЬ (задумливо, у такт музики): Такими були вісім членів бідної родини садівника. Їх вигнали з міста. Те, що лишилося від сім'ї, пішло світом. Десять маленьких негренят - 3 них лишилося дев'ять. Дев'ять маленьких негренят - 3 них лишилося вісім. Вісім маленьких негренят - всі вони потихеньку згубляться, така їх доля. «Гроші правлять світом. Гроші не знають жартів. Гроші вміють лии рахувати, лиш рахувати. А який з бідняка рахунок? Бідняк мусить щезнути!» (Перекрикує текст пісні). Проте я вважаю, ми теж вміємо рахувати. (Змінює тон, стає дедалі гучнішим:) Руйнувати сім'ї, людей розпорошувати як порох - ось, що вміють гроші - цей грубий тесля, великий ремісник! [Döblin 1931, c. 225].

\footnotetext{
${ }^{1}$ Тут і далі переклад Л. Федоренко.
} 
Сцена 3 показує заможне подружжя, яке попри своє фінансове благополуччя також зазнає поразки. Люсі, дочка підприємця, за волею батька вигідно одружується з Георгом - партнером батька. Майже одразу після весілля жінка дізнається, що в чоловіка $є$ коханка, і хоче розірвати їхній шлюб. Побоюючись скандалу та краху бізнесу, батько Люсі наймає людину, яка спеціалізується на «захисті сучасних шлюбів» і яка «допомагає» молодому подружжю: 3 метою економічної вигоди Люсі і Георг продовжують жити під одним дахом, зберігаючи назовні ілюзію сімейного благополуччя. Наприкінці сцени з'являються персонажі перших двох сцен, милуються щасливим «фасадом» буржуазного шлюбу, не відаючи, що він так само зазнав краху.

Порівняльно-зіставний аналіз п’єси «Шлюб» дає підстави виокремити численні мистецько-естетичні ознаки жанру Lehrstück, притаманні п’ссі А. Дьобліна:

$\checkmark$ відмова від театральних декорацій, реквізиту: «Сцена - простий подіум, жодних декорацій та реквізиту. [...] Реквізит не використовувати. Де він необхідний - стілець, лавка - слід уникати будь-якого натуралістичного враження» (Див. авторські «Вказівки» до п’сси) [Döblin 1931];

$\checkmark$ подібно до брехтівських Lehrstück, складовим елементом яких була музика, п’єса «Шлюб» також містить інтегровані музичні пасажі, написані композитором Каролом Ратхаузом (1895-1954). «Музика в п’єсі [...] є обов’язковою», - наголошує А. Дьоблін у «Вказівках» до «Шлюбу»;

$\checkmark$ залучення текстових та ілюстративних проєкцій, які складали загальний коментар до змісту окремих сцен: «На заднику натягнутий екран, на якому проєктуються статичні картини і текст»;

$\checkmark$ використання зонгів, речитативів з музичним супроводом: «Часто-густо в текстовій канві відбувається перехід від мови до співу: часом у формі пісенних пасажів, але переважно це прості речитативи під музичний супровід»;

$\checkmark$ наявність промовця (коментатора) та/або хору, які тлумачать дійство: «Коментатор присутній в усіх сценах. Він виконує функцію хору, роз'яснює слухачам предметно-людські зв'язки в подієвій канві, оцінює та робить висновки». [...] Приблизно наприкінці прологу початок сцени відкривається словами коментатора: «Це війна»;

$\checkmark$ коментар автора виголошує тему та проблематику драми, а також пояснює, як побудована п’єса, підкреслює імовірний виховний, просвітницький, повчальний вплив: «П'єса містить пролог та три сцени: «Молоде подружжя», «Велика родина», «Буржуазний шлюб». П'єса представляє в розрізі взаємовплив сучасної економіки та людських форм побутування, як-от шлюб та сім'я. П'єса демонструє: сучасна економіка має згубний та нищівний вплив на старі форми побутування - шлюб та сім'ю, проте і не спроможна їх організувати та впорядкувати по-новому, їй байдужі людські відносини», «Дві перші сцени відображають владу грошей, остання сцена показує цю владу у власному домі»;

$\checkmark$ наявні також режисерські ремарки, які роз'яснюють можливості сценічного втілення п’єси: «Послідовність сцен така: 1. Молоде подружжя, 2. Велика родина (дві пролетарські сцени), 3. Буржуазний шлюб. Така послідовність логічна. [...] В театрі була апробована також така послідовність: 1. Молоде подружжя, 2. Буржуазний шлюб, 3. Велика родина. При чому «Буржуазний шлюб» був представлений у 
скороченому вигляді як оперета між першими пролетарськими сценами»;

$\checkmark$ можливість імпровізації та випущення окремих сцен відповідно до мети та виду постановки: «Для постановки можливі такі варіанти:

$\checkmark$ кожна сцена може ставитися сама по собі, оскільки дія кожної з них є самодостатньою та логічно завершеною. Така реалізація згодиться до робітничих сцен;

$\checkmark$ сцени 1 та 2 з або без прологів годяться для театрального вечора;

$\checkmark$ сцена 3 без скорочень та уривки перших двох наприкінці годяться для театрального вечора;

$\checkmark$ п'єса може бути поставлена загалом, з випущенням певних елементів, наприклад з вилученням інтермедії та прологу або з його скороченням;

$\checkmark$ наявність епічних елементів, які надають п’єсі «[...] простого, ревюподібного, розповідного плину»;

$\checkmark$ п’єса не створює жодної ілюзії театрального видовища: «Зміна сцен відбувається без цезур, затемнення, звуку гонга чи чогось подібного. Персонажі відкрито з'являються на сцені і покидають сцену» [Fedorenko 2019].

Отже, можна зробити висновок, що п’єса А. Дьобліна «Шлюб» налічує низку естетико-типологічних ознак, які споріднюють ії з «навчальними» п'єсами Б. Брехта, а тому може розглядатися як концептуальне наслідування та/або продовження теорії й практики авторського жанру Lehrstück. Утім, «Шлюб»є єдиною опублікованою п'єсою у творчості А. Дьобліна, написаною в жанрі Lehrstück. Вочевидь, вона стала i залишилася одним iз мистецьких експериментів у доробку автора славетного роману «Берлін Александрплац»на відміну від Б. Брехта, який послідовно розвивав жанр у твоїй драматургії, залишивши поряд із театральними текстами низку теоретичних міркувань щодо жанру. Зокрема, відомо про майже 90 висловлювань Брехта та 25 - його співавторів про жанр Lehrstück, серед яких «Велика і Мала педагогіки» (1930), «Теорія навчально-виховних установ» (1930), «Непорозуміння щодо Lehrstück» (1932), «Німецький театр двадцятих років» (1936), «До теорії Lehrstück» (1937), «Розмова про «Захід» (1957) та інші. Як «лабораторія епічної драми» [Чирков 1981, с. 54], жанр Lehrstück став, з одного боку, проміжною, перехідною ланкою між експресіоністськими п’єсами Б. Брехта («Ваал», «Барабани вночі») та епохальними епічними драмами («Матінка Куріж та їі діти», «Життя Галілея» тощо) [Федоренко 2021, с. 197-198], з іншого боку, Б. Брехт ніколи не полишав думки про Lehrstück i постійно повертався до міркувань про жанр i до театральних експериментів 3 ним. Саме за цією драматургічною формою, враховуючи їі соціально-політичний, філософський та мистецький потенціал, Б. Брехт бачив «майбутнє театру» [Brecht 1972, с. 262-266; Федоренко 2013, c. 307]. Подібне міркування висловив свого часу і французький поет Анрі Гільбо (1885-1938) у праці «Театр майбутнього» (див. «Берлінер тагеблат» від 8 квітня 1929 р.): «Театр має повчати, не вдаючись до наставницько-моралістичної манери школи. Притча (Parabel) - те, що Берт Брехт називає Lehrstück, - $\epsilon$, без сумніву, одним з різновидів театру майбутнього» [Hartung 2004, с. 96].

Перспективним вектором подальших досліджень жанру може стати драматургія сучасних німецькомовних драматургів, зокрема п’єса «Ода» Томаса Мелле, а також творчість інших митців, яких можна розглядати в контексті постдраматичного та постбрехтівського театру: Деа Лойєр, Олівер Буковскі, Роланд Шімельпфеніг, Томас Фрайєр. 


\section{ЛІТЕРАТУРА}

Брехт, Б. (2009). Lehrstücke («навчальні» n’єси). Житомир, 224 с.

Федоренко, Л. (2021). Брехтівський театр: жанрове різноманіття, основні поняття i концепції. [У:] Філологічний часопис, вип. 1 (17), с. 196-204. https://doi.org/10.31499/24158828.1.2021.232741.

Федоренко, Л. (2013). «Захід» Б. Брехта: трагедія чи «навчальна вправа»? [У:] Вісник Житомирського державного університету імені Івана Франка. Філологічні науки, вип. 70, с. 303308.

Федоренко, Л. (2020). (Пост)-брехтівський театр: Lehrstück як макросистема. [У:] Вісник Університету імені Альфреда Нобеля. Серія «Філологічні науки». Дніпро, вип. 1 (19), с. 113-120. Київ, 159 с.

Чирков, О. (1981). Бертольт Брехт. Життя і творчість. Класики зарубіжної літератури.

Чирков, О. (2009). Діалектичний театр - театр епічний? [У:] Вісник Житомирського державного університету імені Івана Франка, вип. 44, с. 183-188.

Чирков, О. (2006). Драматургія - мистецтво драми? [У:] Вісник Житомирського державного університету імені Івана Франка, вип. 30, с. 104-109.

Brecht, B. (1978). Die Lehrstücke. Herausgegeben von B. K. Tragelehn, Verlag Philipp Reclam jun. Leipzig, $346 \mathrm{~S}$.

Brecht, B. (1972). Die Maßnahme. Kritische Ausgabe mit einer Spielanleitung von Reiner Steinweg. Frankfurt a. M., 602 S. $106 \mathrm{~S}$.

Döblin, A. (1931). Die Ehe. 3 Szenen und ein Vorspiel von Alfred Döblin. (1.-3. Aufl.). Berlin,

Fedorenko, L. (2019). Alfred Döblin vs. Bertolt Brecht: zur Rezeption des Genres Lehrstück in Döblins Werk. [In:] Conferinţa ştiinţifică «Probleme de filologie : aspecte teoretice şi practice». Ediţia a 5-a, 07 decembrie 2018 / resp. ed.: Ana Pomelnicova. Bălţi: S. n. (Tipogr. «Indigi Color»), p. 66-71. URL: http://dspace.usarb.md:8080/jspui/bitstream/123456789/4465/1/conf_probl_fil5.pdf (дата запиту: 02.09.2021).

Hartung, G. (2004). Der Dichter Bertolt Brecht. Zwölf Studien. Gesammelte Aufsätze und Vorträge in $5 \mathrm{Bd}$. Leipzig, $452 \mathrm{~S}$.

Knopf, J. (2002). Brecht Handbuch in fünf Bänden. Stuttgart, 679 S.

Krabiel, K.-D. (1993). Brechts Lehrstücke: Entstehung und Entwicklung eines Spieltyps. Stuttgart; Weimar, $472 \mathrm{~S}$.

Müller, H. \& Silberman, M. (1986). To Use Brecht without Criticizing Him Is to Betray Him. [In:] Theater, 17 (2), pp. 31-33.

Prangel, M. (1987). Alfred Döblin. 2., neubearbeitete Auflage. Stuttgart, 131 S.

Steinweg, R. (1976). Das Lehrstück: Brechts Theorie einer politisch-ästhetischen Erziehung. Stuttgart: Metzler, $284 \mathrm{~S}$.

Steinweg, R. (2005). Lehrstück und episches Theater. Brechts Theorie und die theaterpädagogische Praxis. Frankfurt a.M., 190 S.

Vaßen, F. (1995). Bertolt Brechts «learning-play»: Genesis und Geltung des Lehrstücks. [In:] The Brecht Yearbook, 20. Madison, Wisconsin, p. 200-215. 